\title{
Reproductive and Growth Performance of Rabbit Fed Different Inclusion Levels of African Yam Bean (Sphenostylis stenocarpa)
}

\author{
Chikaodiri H. Onuoha*, Bassey J. Harry, James O. Fayenuwo, Emmanuel S. Durotoye \\ Livestock Improvement Programme, Institute of Agricultural Research and Training, Obafemi Awolowo University, \\ Apata Ibadan, Nigeria \\ Email: *chikaodiri4change@yahoo.com
}

How to cite this paper: Onuoha, C.H., Harry, B.J., Fayenuwo, J.O. and Durotoye, E.S. (2020) Reproductive and Growth Performance of Rabbit Fed Different Inclusion Levels of African Yam Bean (Sphenostylis stenocarpa). Open Journal of Animal Sciences, 10, 301-312.

https://doi.org/10.4236/ojas.2020.102018

Received: February 11, 2020

Accepted: April 27, 2020

Published: April 30, 2020

Copyright $\odot 2020$ by author(s) and Scientific Research Publishing Inc. This work is licensed under the Creative Commons Attribution International License (CC BY 4.0).

http://creativecommons.org/licenses/by/4.0/

\begin{abstract}
A feeding trial was conducted to determine the effect of dietary inclusion of Processed African Yam Bean (AYB) at 0\%, 10\%, 20\% and 30\% levels respectively, on the growth and reproductive performance of Rabbits. The AYB inclusion was to ascertain the best (\%) level that would give better performance in rabbits. Complete randomized design was used to allot twenty (20) grower rabbits of both sexes into four treatments in three replicate with each group having three does and two bucks. Each of the treatment diets formulated at different growth stages was fed to the rabbits. The rabbits were kept in hutches inside the rabbit house and given feed and water ad libitum. Growth and reproductive parameters were measured. The proximate analysis and anti-nutritional factor of processed AYB showed that it contained values of $26.88 \%, 92.97 \%$, $5.26 \%, 61.89 \%, 7.04 \%, 3.79 \%$ and $2.17 \%$ for Crude protein, Dry matter, Crude fibre, Nitrogen-free extract, Moisture content, Ash content and Ether extract respectively while the anti-nutritional factor contained $0.11 \%, 14.02 \mathrm{mg} / \mathrm{g}$, $0.19 \mathrm{mg} / \mathrm{g}, 0.21 \mathrm{mg} / \mathrm{g}, 0.14 \mathrm{mg} / \mathrm{g}, 0.21 \mathrm{mg} / \mathrm{g}, 0.13 \mathrm{mg} / \mathrm{g}$ and $0.01 \mathrm{mg} / \mathrm{g}$ of Tannin, Alkaloid, Oxalate, Phytate, Saponin, Flavonoids, Trypsin inhibitor and Lectin. From this study, the rabbit group on $10 \%$ AYB inclusion significantly $(\mathrm{p}<0.05)$ recorded better growth rate and reproductive performance than the rest of the treatment groups. The group on diets $20 \%$ and $30 \%$ inclusion recorded different results on linear body measurement which were significantly $(\mathrm{p}<0.05)$ lower compared to control group. The body weights of the animals were not significantly $(\mathrm{p}>0.05)$ affected by the diets. The results of this experiment concluded that AYB can be included in the diet of rabbits with $10 \%$ inclusion giving a better reproductive performance and growth rate without any negative effect.
\end{abstract}




\section{Keywords}

Rabbits, Africa Yam Bean, Reproductive Performance, Growth, Anti-Nutritional Factor

\section{Introduction}

Rabbit (Oryctolagus cuniculus) is one of the most productive animals among other domesticated livestock, their feeding habit is in no competition with humans and their optimum performance can only be ensured in a mixed feeding regime involving forage and formulated feeds without compromising their reproductive efficiency [1]. African Yam Bean (AYB) is one of the underutilized legumes with high protein content which is gradually going into extinction due to low production from crop farmers and low consumption rate by both human beings and animals. Readiness in the implementation of most of the research findings on the nutritional possibilities in the AYB may meet some challenges especially that of producing the grains in commercial quantity since the producers are presently few [2]. AYB is a good source of protein, carbohydrate, minerals and vitamins with its protein content, twice that of sweet or Irish potatoes and very much higher than those in yam and cassava [3]. Many research documents revealed the efficiency of various processing techniques in reducing the Anti-nutritional factor content in AYB as well as reducing the cooking times of its meals. Good processing assures safety consumption of AYB meals by human and livestock [2]. It is mainly used as food and can also be used to feed animals [4].

Incorporating AYB in the feeds of some livestock has been attempted by [5] [6]. It can be used in inclusion or as a substitute for protein source in livestock feed provided other food crops used in livestock feed is available to supplement the AYB content for increased feed consumption and palatability [7]. [6] specifically remarked that AYB would be a good alternative protein source for livestock and poultry. It has been used at $15 \%-60 \%$ in Nile Tilapia fingerlings as the dietary protein to substitute for full-fat soya beans in their diet [8].

The success of animal production and reproduction is determined by several interactive factors like genetic make-up of the animal, nutrition, temperature, photoperiod and stress. Among these factors, nutrition has a great influence on the ability to achieve both production and reproduction goals [9], and Protein is one of the essential nutrients in human foods and animal feeds needed for growth and reproduction. Reproductive failure due to inadequate nutrient and oxidative stress causes cell death which is one of the most significant factors that limit the productivity of animal production which results either in huge loss or profit annually [10]. Growth and reproductive performance of animals may be improved by the inclusion of some feedstuff from many legumes as alternative source for 
energy and protein of which AYB is one of them. There is exiguity of information about the nutritional possibility of African Yam bean in improving reproductive performance of livestock animals and according to [11], rabbit farmers are faced with challenges in finding practical, cost effective ways to improve performance without compromising the breeding and production of safe and high quality meat products, hence the need for this study which was aimed at investigating the reproductive and growth performance of grower's rabbits fed varying inclusion levels of African Yam bean.

\section{Materials and Method}

\section{Experimental location and diet preparation}

The experiment was carried out at the rabbit house of Institute of Agricultural Research and Training (I.A.R\&T) Ibadan, located in the humid zone of Rainforest belt 0703.25 of Oyo state in Southwestern part of Nigeria on Latitude $07^{\circ} 23 \mathrm{~N}$ and Longitude $03^{\circ} 51 \mathrm{E}$ with mean annual rainfall of $1220 \mathrm{~mm}$, mean temperature of $26^{\circ} \mathrm{C}$ and relative humidity of $74 \%$ at $650 \mathrm{~mm}$ above sea level. The seeds of African Yam Bean (AYB) used for this experiment were purchased from a local market in Cross River state of Nigeria while other feed ingredients were bought from Adom Agroallied feed service in Odo-Ona, Apata. The seeds were parboiled in hot water for 20 mins, sieved out and sundried for 4 days after which it was grounded using grinding machine and the samples taken to the Laboratory for anti-nutritional factor and proximate analysis before its use in formulation of the rabbit diets. Samples were analyzed chemically using the methods described by [12] for proximate analysis and the methods described by [13] [14] [15] and [16] for that of anti-nutritional factor and all analysis based on 100\% dry matter.

\section{Experimental diets}

At different stages of growth within the period of the experiment (grower to adult and gestation to lactation stages respectively), two different basal diets were formulated so as to meet the maximum nutrients required by the rabbits. Dietary treatments consisted of basal diets with $0 \%$ inclusion of AYB (control diet; $\left.\mathrm{T}_{1}\right), 10 \%$ inclusion $\left(\mathrm{T}_{2}\right), 20 \%\left(\mathrm{~T}_{3}\right)$ and $30 \%\left(\mathrm{~T}_{4}\right)$ respectively and all formulation were based on $100 \%$ total digestible nutrient (TDN).

\section{Experimental animals and design}

Twenty (20) grower rabbits comprising of 12 females and 8 males purchased from cotonou were used for the experiment. A completely randomized design was used to allot the animals into four treatments which comprises of 3 female and 2 male per treatment. The animals were allowed to acclimatize for 14 days, basal diets formulated and water was supplied ad libitum to the animals. The practical use of the animals before and after the experiment was conducted under the conditions of ethical approval of animal care without violation of any rules.

\section{Data collection and Statistical analysis}

Parameters determined were initial and final weight of the animals to adult stage (recorded at the beginning of the experiment and subsequently on weekly 
basis till the adult stage), feed conversion ratio, body weight gain, growth rate on linear body measurement (all in $\mathrm{cm}$ ) libido in bucks (Reaction time), onset of puberty, age at first mating, Gestation length, age at first conception, litter size at birth, mortality rate from birth to weaning etc. All data obtained were subjected to one way analysis of variance (ANOVA) using statistical analysis Software (SAS, 2004) version 9.0 software. Differences in means were separated by Duncan's multiple Range test (DMRT) of the same software at 5\% (0.05) level of significance and $95 \%$ confidence.

The Linear body measurements were taken using flexible measuring tape. Animals was meant to stand upright and restrained by an assistant in a way that the head, neck, ears and body were stretched in a straight line during the body measurement. Tail length measured as the distance from the base of the tail to the tip $(\mathrm{cm})$, Body length measured as distance from the tip of the shoulder to the base of the tail (point of hip), Heart girth measured as the circumference of the narrowest point just behind the shoulder perpendicular to the circumference of the body $(\mathrm{cm})$, Neck circumference measured as the circumference of the neck at the midpoint by flexing the tape around the neck behind the ears, Ear length measured as the distance from the base of the ear to the tip $(\mathrm{cm})$, Head to shoulder measured as the distance from the tipoff the nose to the end of the shoulder, Fore limb measured as the distance from the fore toe nail to the shoulder and the Hind limb measured from the tip of the toe nail to the hock.

Body weight of the animals was calculated as (the final body weight - initial body weight) using a sensitive weighing balance while the average daily wt. gain was deducted as (final weight gain - initial body weight $\div$ by Number of days for the feeding trials). Total feed intake was calculated by subtracting the total quantity of left over feed from the total quantity of feed given over the period of time (Total qnty of feed given - Total qnty of left over feed), while the Feed conversion ratio was calculated as quantity of feed consumed divided by body weight gain (quantity of feed consumed $\div$ body weight gain).

Reproductive performance of the rabbits was measured by evaluating their sexual behavior and mating ability beginning at the expected age of attainment of puberty. The sex drive of the bucks (Libido) were measured by recording the interest of the buck and the time in seconds (with a stopwatch) that it took the buck to sniff, tease and mount the female and the number of mounts to accomplish ejaculation after which the result was rated using the scoring pattern described by [17], as shown in Table 7. Other reproductive performance of does such as Total litter size at birth was measured as the Number of kits/per doe/per cycle, Mortality rate of kit measured as the total No. of kits at birth subtracted by total No. of kit at weaning period. Litter size at weaning measured as the No. of kit that survived till the weaning stage while the Litter weight at 28 days also referred as the milk production rate of a doe, was calculated as the litter weight by 28 days post-partum. 


\section{Results}

The results of the proximate analysis of the processed AYB, Anti-nutritional factors, linear body measurement and body weight gain (growth performance) of grower's rabbits fed different inclusion of African Yam Bean diets are shown in Tables 1-4 while that of their reproductive performance are shown in Table 5 and Table 6 respectively.

The scoring pattern of description for levels of libido in rabbit as described by [17] is represented in Table 7 below.

Table 1. Proximate analysis of processed African Yam Bean (AYB).

\begin{tabular}{cc}
\hline Proximate fractions & Composition value (\%) \\
Crude protein & 26.88 \\
Dry matter & 92.97 \\
Crude fibre & 5.26 \\
Nitrogen free extract & 61.89 \\
Ash content & 3.79 \\
Moisture content & 7.04 \\
Ether extract & 2.17 \\
\hline
\end{tabular}

Table 2. Anti-nutritional factor (ANF) composition of processed AYB.

\begin{tabular}{cc}
\hline Parameters & Composition value $(\mathrm{mg} / \mathrm{g})$ \\
\hline Tannin & $0.113 \%$ \\
Alkaloids & 14.020 \\
Oxalate & 0.188 \\
Phytate & 0.213 \\
Saponin & 0.141 \\
Flavonoids & 0.212 \\
Trypsin inhibitor & 0.126 \\
Lectin & 0.013 \\
\hline
\end{tabular}

Table 3. Results on Linear body measurement of experimental animals.

\begin{tabular}{cccccc}
\hline Parameters & $\mathrm{T}_{1}$ & $\mathrm{~T}_{2}$ & $\mathrm{~T}_{3}$ & $\mathrm{~T}_{4}$ & Error mean sq. \\
\hline Tail length & $7.36^{\mathrm{a}}$ & $7.56^{\mathrm{a}}$ & $7.14^{\mathrm{a}}$ & $7.34^{\mathrm{a}}$ & \pm 0.1037 \\
Body length & $31.97^{\mathrm{a}}$ & $31.24^{\mathrm{a}}$ & $31.08^{\mathrm{a}}$ & $32.23^{\mathrm{a}}$ & \pm 1.5044 \\
Heart Girt & $22.96^{\mathrm{a}}$ & $22.54^{\mathrm{a}}$ & $21.78^{\mathrm{a}}$ & $21.72^{\mathrm{a}}$ & \pm 1.9443 \\
Neck circumference & $12.56^{\mathrm{a}}$ & $12.36^{\mathrm{ba}}$ & $12.29^{\mathrm{ba}}$ & $11.62^{\mathrm{a}}$ & \pm 0.4528 \\
Ear length & $11.12^{\mathrm{a}}$ & $10.94^{\mathrm{a}}$ & $10.97^{\mathrm{a}}$ & $11.17^{\mathrm{a}}$ & \pm 0.3013 \\
Head to shoulder & $10.82^{\mathrm{a}}$ & $10.31^{\mathrm{bc}}$ & $10.05^{\mathrm{c}}$ & $10.58^{\mathrm{ba}}$ & \pm 0.0690 \\
Fore limb & $15.66^{\mathrm{a}}$ & $15.30^{\mathrm{a}}$ & $15.12^{\mathrm{a}}$ & $15.40^{\mathrm{a}}$ & \pm 0.3087 \\
Hind limb & $23.20^{\mathrm{a}}$ & $23.00^{\mathrm{a}}$ & $22.99^{\mathrm{a}}$ & $23.33^{\mathrm{a}}$ & \pm 0.3980 \\
\hline
\end{tabular}

a,b,c Means with the same superscripts in a row are not significantly difference $(p>0.05)$. 
Table 4. Body weight gain (Growth performance) of experimental animals fed different inclusion level of AYB.

\begin{tabular}{ccccc}
\hline Parameters & $\mathrm{T}_{1}$ & $\mathrm{~T}_{2}$ & $\mathrm{~T}_{3}$ & $\mathrm{~T}_{4}$ \\
\hline Initial weight $(\mathrm{kg})$ & 635.30 & 626.60 & 656.50 & 634.30 \\
Final weight $(\mathrm{kg})$ & $1361.40^{\mathrm{a}}$ & $1391.20^{\mathrm{a}}$ & $1276.40^{\mathrm{a}}$ & $1370.00^{\mathrm{a}}$ \\
Body weight gain $(\mathrm{kg})$ & $726.10^{\mathrm{a}}$ & $764.60^{\mathrm{a}}$ & $619.90^{\mathrm{a}}$ & $735.70^{\mathrm{a}}$ \\
Ave. daily wt. gain $(\mathrm{kg})$ & $103.73^{\mathrm{a}}$ & $109.23^{\mathrm{a}}$ & $88.56^{\mathrm{a}}$ & $106.49^{\mathrm{a}}$ \\
Total feed intake (g) & $3134.20^{\mathrm{a}}$ & $2933.70^{\mathrm{a}}$ & $2923.16^{\mathrm{a}}$ & $2918.50^{\mathrm{a}}$ \\
Feed conversion ratio & $4.36^{\mathrm{ab}}$ & $3.89^{\mathrm{b}}$ & $4.91^{\mathrm{a}}$ & $4.05^{\mathrm{ab}}$ \\
\hline
\end{tabular}

a,b,ab Means within the same row with different superscripts are significantly different $(\mathrm{p}<0.05)$.

Table 5. Reproductive performance of experimental rabbit does.

\begin{tabular}{ccccc}
\hline Parameters & $\mathrm{T}_{1}$ & $\mathrm{~T}_{2}$ & $\mathrm{~T}_{3}$ & $\mathrm{~T}_{4}$ \\
\hline Age at puberty (wks.) & 24.00 & 24.00 & 24.00 & 24.00 \\
Age at first mating (wks.) & 28.00 & 28.00 & 28.00 & 28.00 \\
Age at first conception (wks.) & $30.00^{\mathrm{a}}$ & $28.00^{\mathrm{b}}$ & $30.00^{\mathrm{a}}$ & $30.00^{\mathrm{a}}$ \\
Ave. wt. before mating (kg) & 1.600 & 1.650 & 1.614 & 1.602 \\
Gestation length (days) & $31.00^{\mathrm{a}}$ & $32.00^{\mathrm{a}}$ & $32.00^{\mathrm{a}}$ & $32.00^{\mathrm{a}}$ \\
Total Litter size at birth (Number) & $8.00^{\mathrm{a}}$ & $20.00^{\mathrm{b}}$ & $16.00^{\mathrm{c}}$ & $15.00^{\mathrm{c}}$ \\
Mortality rate of Kits \% (B - W) & 3.00 & 4.00 & 5.00 & 5.00 \\
Litter size at weaning & $5.00^{\mathrm{a}}$ & $16.00^{\mathrm{b}}$ & $11.00^{\mathrm{c}}$ & $10.00^{\mathrm{c}}$ \\
Litter weight at 28 days (g) & $100-120$ & $100-150$ & $100-120$ & $90-120$ \\
Ave. kit weight at weaning (g) & $600^{\mathrm{a}}$ & $2000^{\mathrm{b}}$ & $1210^{\mathrm{ab}}$ & $1050^{\mathrm{ab}}$ \\
\hline
\end{tabular}

${ }^{a, b, c}$ Means within the same row with different superscripts are significantly different $(p<0.05)$.

Table 6. Reproductive performance of experimental rabbit buck.

\begin{tabular}{ccccc}
\hline Parameters & $\mathrm{T}_{1}$ & $\mathrm{~T}_{2}$ & $\mathrm{~T}_{3}$ & $\mathrm{~T}_{4}$ \\
\hline Age at puberty (wks.) & 22.00 & 22.00 & 22.00 & 22.00 \\
Age at first mating (wks.) & 28.00 & 28.00 & 28.00 & 28.00 \\
Age at first successful mating (wks.) & $30.00^{\mathrm{a}}$ & $28.00^{\mathrm{b}}$ & $30.00^{\mathrm{a}}$ & $30.00^{\mathrm{a}}$ \\
Ave. wt. before mating (kg) & $1.652^{\mathrm{a}}$ & $1.685^{\mathrm{a}}$ & $1.650^{\mathrm{a}}$ & $1.654^{\mathrm{a}}$ \\
Sex drive \% (Libido/reaction time) & $4^{\mathrm{a}}$ & $5^{\mathrm{ab}}$ & $4^{\mathrm{a}}$ & $4^{\mathrm{a}}$ \\
\hline
\end{tabular}

${ }^{\mathrm{a}, \mathrm{b}}$ Means within the same row with different superscripts are significantly different $(\mathrm{p}<0.05)$.

Table 7. Scores and description for levels of Libido (sex drive) in rabbit.

\begin{tabular}{ccc}
\hline Levels (\%) & Rate & Description \\
\hline 5 & High & Grooms (tease) Sniff and Mounts \\
4 & Lormal & Grooms (tease) and Sniff only \\
2 & Very low & Sniff only \\
1 & No libido & Goes not pay attention to the female \\
\hline
\end{tabular}

Source: [17]. 


\section{Discussion}

Results of proximate analysis shown in Table 1 indicated that AYB used for this study, Figure 1 is a promising plant and has sufficient nutrients to meet the nutrient requirements of rabbits. The low moisture content of (7.04) favored the storage of AYB since high moisture content hastens spoilage of feedstuff and enhance microbial growth [18].

The crude protein content of $26.88 \%$ obtained for processed AYB meal is an indication that it can be used in rabbit diets as supplementary source of protein. This result is in line with the findings of [19] which reported range of $25.4 \%$ $28.6 \%$ of crude protein level for optimum performance such as maintenance, normal growth and pregnancy. However, the percentage crude protein obtained for AYB in this study is higher than the value reported by [4] who reported the crude protein content of processed AYB as $22.52 \%$. These differences may be due to climatic variations coupled with the AYB variety or cultivar type used for the study.

Ash content value (3.79) recorded in this study shows that AYB could be a potential source of minerals for rabbit, however the ash content obtained in this study is an indication that AYB should not be used solely as a feedstuff for rabbit rather should be mixed with other feedstuff with lower ash content. This is in agreement with the findings of [20] who opined that plant material intended for use in feed formulation should have ash content less than $2.5 \%$.

The Nitrogen free extract (NFE) content of (61.89) and the metabolizable energy $(\mathrm{ME} / \mathrm{Kcal} / \mathrm{kg})$ value of $(3367.4 \mathrm{kcal} / \mathrm{kg})$ obtained from AYB used in this study is an indication that AYB could be a supplementary source of energy to support the growth and reproductive performance of rabbits. However, this (ME) Value is higher than the recommended value by [21], who reported that rabbits generally grow well when fed with a diet with energy range between 2600 - $2700 \mathrm{kcal}$ metabolizable energy. The result agrees with that of [22] who reported that cooked seeds of AYB have higher fibre content, high efficiency of protein digestibility, higher amino acid availability, high gross and metabolizable energy and good fatty acid profile.

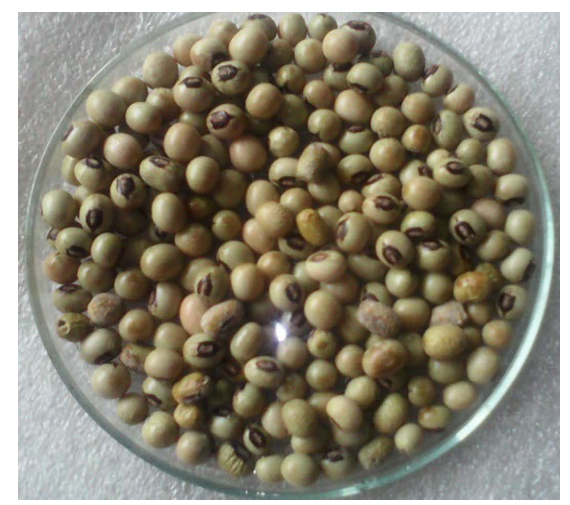

Figure 1. Shows the sample of African Yam Bean seed used for the study. 
Anti nutritional composition of the AYB used for the study is represented in (Table 2). Anti-nutritional factors (ANF) in food legumes are chemical substances present in products; although non-toxic but generate adverse physiological responses in animal that consumes them [2]. In most cases, ANF interferes with the utilization of nutrients in legume products [22], their presence could cause flatulence. The ANF values obtained from this study fell within the range of values as reported by [23] on Proximate, Antinutrients and Mineral Composition of Raw and Processed (Boiled and Roasted) Sphenostylis stenocarpa Seeds from Southern Kaduna, Northwest Nigeria.

Table 3 \& Table 4 show the results of the linear body measurement and growth performance of grower's rabbit fed dietary levels of AYB. There were significant ( $p>0.05$ ) differences in some of the parameters measured including the final weight and weight gain. The significance observed in some of the linear growth of rabbits fed dietary levels of AYB meal relative to the control animals are indication that the inclusion of the test ingredient up to $30 \%$ level has effects on their growth especially on their neck and head to shoulder. Research on linear body measurements have been used to evaluate breed performance, predict live weight gain, and to examine reproductive performance [24]. The animals fed with diets containing $10 \% \mathrm{AYB}$ had the value of $1391.20 \mathrm{~g}$ as their final weight which was significantly $(\mathrm{p}<0.05)$ better than those fed with diets containing $20 \%$ and $30 \%$ having values of $1276.40 \mathrm{~g}$ and $1379.70 \mathrm{~g}$ respectively, this is equivalent to their weight gain.

Rabbit on control diets ( $0 \% \mathrm{AYB})$ had the second to the highest weight gain $(726.10 \mathrm{~g})$ whereas the animals on diet containing $10 \%$ AYB significantly $(\mathrm{p}<$ $0.05)$ had the highest and better result $(764.60 \mathrm{~g})$ in weight gain, meanwhile results obtained for those on diets containing $20 \%$ and $30 \%$ were not statistically ( $p>0.05)$ different and are comparable to those on control diet. This result is similar to the report by [4], these authors reported that final weight and weight gain were significantly higher in finisher broiler fed with AYB. The low final weight and weight gain recorded from rabbits fed $20 \%$ and $30 \%$ AYB may be due to low feed intake and low energy efficiency owing to the presence of high fibre content and anti-nutritional factor in the $20 \%$ and $30 \%$ levels of AYB. This observation is in agreement with the findings of [6] who have applied AYB seeds in weaner rabbit diets as a substitute for soya bean at $10 \%$ inclusion.

The results recorded for feed intake showed no significant $(p>0.05)$ difference across the dietary treatment except for the feed conversion ratio which was statistically $(\mathrm{p}<0.05)$ different for the animals fed diets containing 10\% AYB when compared with control diets, group 3 and 4 containing 0\%, 20\%, 30\% AYB. This is an indication of acceptability by the animal at $10 \%$ inclusion level.

Feeding African Yam Bean meal (AYBM) diets up till 30\% level of inclusion did not influence $(\mathrm{p}>0.05)$ gestation length, age at puberty, average weight before mating, age at first mating and mortality rate for both the does and buck respectively, whereas total litter size, litter size at weaning, Average kit weight at weaning and age at conception and age at first successful mating by the bucks, 
were significantly different $(\mathrm{p}<0.05)$ within the groups with the best reproductive performance (Table 5) recorded in the group of animals fed $10 \%$ inclusion level of AYB. This could be attributed to high consumption of the diets due to its palatability and balanced nutrients leading to the high reproduction of kits from birth to weaning stage and successful conception even when they were mated at the same period with other females in control group, group 3 and 4 fed $0 \%, 20 \%$, $30 \%$ inclusion level of AYB. Values of gestation length obtained in this study (31 - 32 days) fell within the range of 30 - 32 days reported by [25] for rabbits. Kit mortalities did not show any significant difference $(p>0.05)$ between the groups. There was no kits born dead during the study though death of some kits occurred after some days, this implies that despite the inclusion of AYB up to 30\% in the diets of gestating rabbit does, there was no interference with development of the kits in the uterus.

Consequently, the result of sex drive (Libido/reaction time) for the buck as represented in Table 6 showed significant difference $(\mathrm{p}<0.05)$ across the treatment. The time in seconds that it took the rabbit bucks to sniff, groom and mount the female which was recorded with a stop watch was used to calculate the sex drive and the libido scored using the scoring pattern described by [17] as shown in Table 7. Rabbit buck in group 2 fed with 10\% inclusion level of AYB had the highest score followed by control group which exhibited normal sexual activities. When compared with other treatment groups, bucks fed $10 \%$ inclusion level of AYB, exhibited a better sexual activeness, this also followed the same trend with their age at first successful mating (Figure 2 and Figure 3 ). The result signifies that AYB could be a good sexual activator for better performance. This is in agreement with [26] who reported that the kind of nutrition given to an animal can affect its libido and the quality of semen being produced.

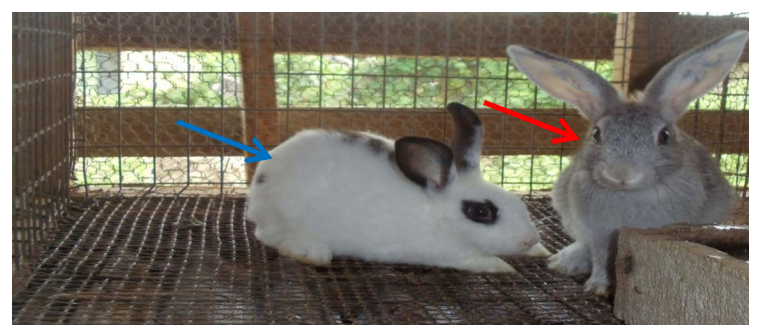

Figure 2. Shows a buck (blue arrow) resting after ejaculation indicating successful mating with the female counterpart (red arrow).

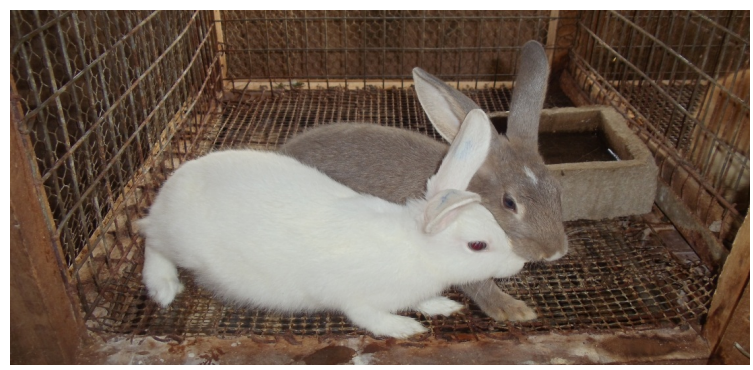

Figure 3. Shows nourished pregnant does resting in their hutch inside the rabbitry. 
The Performance of does during lactation which was obtained by calculating the average kit weight at 28 days and at weaning showed significant difference ( $\mathrm{p}$ $<0.05)$. Both litter weights at 28 days and average wt. of kits at weaning used as an indicator of milk production by does, were affected by AYB inclusion in the diets especially at the $20 \%$ and $30 \%$ level. This could be as a result of low feed intakes associated with the feed due to palatability problem which eventually affected their kits weight in attaining the stage of nibbling at their feed (25 - 27 days post-partum) having difficulty in consuming their feed. This could also be linked to poor feed utilization due to high content of crude fibre and antinutritional factors at that $20 \%$ and $30 \%$ inclusion level. This result agrees with the report of an earlier study by [27] on reproductive performance of rabbit does fed diets containing Gliricidia leaf meal from conception through weaning of kits. The positive relationship between litter size at birth, at 28 days and at weaning imply that the higher the No of kits born per litter per doe (kits born/litter/doe), the higher the No. weaned/litter/doe. Litter size at weaning is considered as a good practical yardstick to measure the profitability of any animal production venture [28] therefore, breeding for litter size coupled with feedstuff like AYB without adverse effect, would enhance the profitability of animal production involving rabbit. The result of this study indicated that palatability problems associated with feedstuff with high crude protein and antinutritional factors like AYB incorporated into diets of breeding rabbit does and buck, can depress feed intake coupled with poor metabolism of the feed, this can lead to low birth rate, litter size and poor milk production as well as the inability of the young rabbit to utilize the AYB diets appropriately.

\section{Conclusion}

Inclusion of African Yam Bean meal in rabbit diets has no negative effect on the growth and reproductive performance of rabbits as observed in the result presented, the best performance being recorded in group 2 fed with $10 \%$ inclusion level. It therefore signified that AYB can serve as an alternative feed resource in rabbit diets with inclusion level of $10 \%$ for better performance without any deleterious effect. However, further research is recommended to evaluate its effects on the semen quality, sperm concentration, sperm motility and other reproductive characteristics of male rabbit as well as its possible effects on rabbit's blood profile.

\section{Conflicts of Interest}

The authors declare no conflicts of interest regarding the publication of this paper.

\section{References}

[1] Arijeniwa, A., Otaikhian, S.O. and Maseun, J.A. (2000) Performance of Weaner Rabbits Fed: Grower Supplemented with Different Grass Legumes Rations. In: Proceedings of 5 th Annual Conference of Animal Science Association of Nigeria (ASAN), 103-105. 
[2] Adewale, B., Daniel, A. and Aremu, C.O. (2013) The Nutritional Potentials and Possibilities in African Yam Bean for Africans. International Journal of AgriScience 3, 8-19.

[3] Liday, L. (2013) Protein from Land Plants Potential Resources for Human Nutrition and Food Security. Trend in Food Science and Technology, 32, 25-42. https://doi.org/10.1016/j.tifs.2013.05.005

[4] Onunkwo, D.N., Anyaegbu, B.C., Ezike, J.C. and Daniel-Igwe, G. (2019) Dietary Substitution of Soya Bean Meal with Processed African Yam Bean Meal as Protein Source in the Diets of Finisher Broilers. Nigerian Journal of Animal Production, 46, 118-127.

[5] Agunbiade, S.O. and Longe, O.G. (1999) African Yam Bean Hull Chemical Composition and Its Effects on Rat's Mineral Retention, Serum Biochemical Components and Enzymatic Activities. Nahrungsmittel, 42, 89-93. https://doi.org/10.1002/(SICI)1521-3803(199804)42:02<89::AID-FOOD89>3.0.CO;2-Q

[6] Akinmutimi, A.H., Amaechi, N. and Unuog, M. (2006) Evaluation of Raw African Bean as Substitute for Soyabean in the Diet of Weaner Rabbits. Journal of Animal Veterinary Advances, 5, 907-911.

[7] Onuoha, C.H., Harry, B.J. and Eze, S.O. (2017) Evaluation of Nutrients and Anti-Nutritional Factors of Different Species of African Yam Bean (Sphenostylis stenocarpa). European Journal of Basic and Applied Sciences, 4, 1.

[8] Alegbeleye, S.O. (2002) Evaluation of African Yam Bean (Sphenostylis sternocarpa Hotchst ex Arich) as a Replacement for Soya Bean in the Diets of Nile Tilapa (Oreochromis niloticus) Fingerlings. Asset Services Agriculture and Environment, 2, 73-79.

[9] Iyeghe-Erakpotobor, G.T. and Ashworth, C.J. (2003) Relationship between Live Weight, Liver Weight and Progesterone Metabolism of Land Race X Large White and Meishan Pigs in Early Pregnancy. ASSET Series A, 3, 1-9.

[10] Etim, N.N., Enyenihi, G.E., Akpabio, U. and Effiong, E.E.A. (2014) Effect of Nutrition on Haematology of Rabbits: A Review. European Scientific Journal, 10, 413-424.

[11] Ewuola, E.O. and Odefemi, T.R. (2019) Growth Response, Organ Morphometry, Sperm Production and Reserve in Rabbit Bucks Administered Carrot Fruit Extracts. Nigerian Journal of animal production, 46, 30-35.

[12] AOAC (2004) Official Methods of Analysis of the Association of Official Analytical Chemists, 20th Edition.

[13] Reddy, N.R. Sathe, S.K. and Salunkhe, D.K. (1982) Phytates in Legumes and Cereals. Advances in Food Research, 28, 1-92. https://doi.org/10.1016/S0065-2628(08)60110-X

[14] Arntfield, S.D. Ismond, M.A.H. and Murray, E.D. (1985) The Fate of Anti-Nutritional Factors during the Preparation of the Faba Bean Protein Isolate Using Micellization Techniques. Canadian Institute of Food Science and Technology Journal, 18, 137-143. https://doi.org/10.1016/S0315-5463(85)71771-3

[15] Doss, A., Pugalenthi, M., Vadivel, V.G., Subhashini, G. and Subash, R.A. (2011) Effects of Processing Technique on the Nutritional Composition and Antinutrients Content of under-Utilize Food Legume Canavalia ensiformis L.DC. International Food Research Journal, 18, 965-970.

[16] Leyva, J.A.M., Artiga, M.P.H., Méndez, M.M.A. and Pér, J.J.Q. (1990) Atomic Absorption and UV-VIS Absorption Spectrophotometric Determination of Oxalate in Urine by Ligand Exchange Extraction. Clinica Chimica Acta, 195, 47-56.

https://doi.org/10.1016/0009-8981(90)90193-V 
[17] Chibundu, U.C. (2005) Response of Pre-Pubertal Bucks to Administration of Estradiol $\beta$. Project Report, Federal University of Technology, Owerri, 30.

[18] Afolayan, M., Afolayan, S.B. and Muhammed, M.A. (2019) Dietary Inclusion of Locust Bean Leaf Meal Improved Performance of Weaner Rabbits. Nigerian Journal of Animal Production, 46, 169-176.

[19] Abbey, B.W. and Berezi, P.E. (1988) Influence of Processing on the Digestibility of African Yam Bean (Sphenostylis stenocarpa (Hoechst Ex. A. Rich. Harms) Flour. Nutritional Report International, 37, 819-827.

[20] Akintayo, E.T. (2004) Characteristics and Composition of Parkia biglobosa and Jathropha cureas Oils and Cakes. Bioresource Technology, 92, 307-310. https://doi.org/10.1016/S0960-8524(03)00197-4

[21] Fielding, D. (1991) Rabbits: In Tropical Agricultural Series C.T.A. Macmillan Education Ltd. London, 39-50.

[22] Nwokolo, E.A. (1996) The Need to Increase Consumption of Pulses in the Developing World. In: Food and Feed from Legumes and Oil Seeds, Chapman and Hall, London. https://doi.org/10.1007/978-1-4613-0433-3_1

[23] Uche, S.N., Charity, N., Abbas, O., Aliyu, M., Francis, G.B. and Oche, O. (2014) Proximate, Antinutrients and Mineral Composition of Raw and Processed (Boiled and Roasted) Sphenostylis stenocarpa Seeds from Southern Kaduna, Northwest Nigeria. International Scholarly Research Notices, 2014, Article ID: 280837. https://doi.org/10.1155/2014/280837

[24] Chineke, A., Agavivor, B., Ikeobi, C.O.N. and Ologun, A.G. (2000) Some Factors Affecting Body Weights and Measurements of Rabbits at Pre and Post Weaning Ages. Proceedings of 27 th Annual NSAP Conference, Akure, 1-4.

[25] Lebas, F. (1983) Small Scale Rabbit Production-Feeding and Management Systems. World Animal Review, 46, 11-17.

[26] Adams, A. and Sign, B. (1981) Semen Characteristics and Fertility of Rabbit Subjected to Exhaustive Use. Laboratory Animal, 15, 157-161. https://doi.org/10.1258/002367781780958856

[27] Herbert, U. (1998) Reproductive Performance of Rabbit Does Fed Diets Containing Gliricidia Leaf Meal from Conception through Weaning of Kits. Nigerian Journal of Animal Production, 25, 163-168.

[28] Khalil, M.H. and Mansour, H. (1987) Factors Affecting Reproductive Performance of Female Rabbits. Journal Applied Rabbit Resource, 10, 140-145. 